\title{
The challenges facing the next Chief Executive of Hong Kong in 2022: managing growth, conflict, change and continuity
}

Challenges facing the next Chief Executive

\author{
Regina Suk-yee Ip Lau \\ Legislative Council and Executive Council, Hong Kong SAR, China
}

\begin{abstract}
Purpose - This article outlines the challenges faced by the next Chief Executive of the Hong Kong Special Administrative Region (HKSAR) in 2022 - the need to address economic problems resulting from Hong Kong's slow growth; its inability to restructure its economy to broaden job opportunities and improve upward mobility for young people; and the government's belated attempt to deploy innovation and technology.

Design/methodology/approach - This article is based on the author's in-depth analysis of the current situation and insights on the challenges faced by the next Chief Executive.

Findings - Tensions are inherent in the concept of "One Country, Two Systems". Back in November 2012, Deputy Director of the Hong Kong and Macao Office Zhang Xiaoming already reminded Hong Kong of the need to manage well three sets of relationships: (1) maintaining the "One Country" principle while preserving the SARs' "separate systems"; (2) upholding Central Authority while preserving the SARs' "high degree of autonomy"; and (3) unleashing the economic potential of mainland China while raising the competitiveness of the SARs. These three sets of relationships represent three fundamental difficulties in implementing "One Country, Two Systems". However, Hong Kong kept ignoring Beijing's advice and failed to resolve the tension between the mainland and Hong Kong SAR, culminating in theriotous events of 2019, which morphed into a dangerous, anti-China insurgency. Originality/value - The next Chief Executive needs to mediate between the constitutional requirements of the Central Authority while preserving Hong Kong SAR's "high degree of autonomy", its unique character and lifestyle. He or she also needs to deal with continuity and change. Hong Kong cannot stand still, and should not allow itself to be lulled by the " 50 years no change" mantra into overlooking the need to move with the times. Much reform needs to be implemented by the next Chief Executive to give people hope, faith in "One Country, Two Systems" and true love of the country.
\end{abstract}

Keywords Hong Kong, "One Country, Two Systems", Chief Executive, Challenges

Paper type Viewpoint

\section{Introduction}

President Professor Peter Fong and distinguished members of the Hong Kong Public Administration Association, Honourable Guests, Ladies and Gentlemen,

Let me begin by thanking the HKPAA sincerely for inviting me to speak at your AGM. This is a great honour, and I was delighted to accept the invitation extended by Professor Fong.

The topic originally proposed by Professor Fong was "How can the next Chief Executive lead Hong Kong to re-establish its prosperity and stability?"

I have re-tweaked the title to highlight the specific challenges faced by the next Chief Executive, namely the need to re-invigorate growth, resolve conflict, and manage change and continuity.

(C) Regina Suk-yee Ip Lau. Published in Public Administration and Policy. Published by Emerald Publishing Limited. This article is published under the Creative Commons Attribution (CC BY 4.0) license. Anyone may reproduce, distribute, translate and create derivative works of this article (for both commercial and non-commercial purposes), subject to full attribution to the original publication and authors. The full terms of this license may be seen at http://creativecommons.org/licences/by/4.0/legalcode

This article is based on a keynote speech I delivered at the AGM of Hong Kong Public Administration Association held on 24 June 2021 at Lingnan Club, Central, Hong Kong.
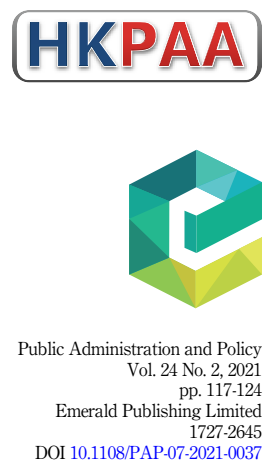
PAP

24,2

118

I re-tweaked the title because Professor Fong's suggestion reminded me of what one of my bosses said to me when I was a small potato toiling at Lower Albert Road, some 45 years ago. He said to me, on taking over a new schedule of responsibilities - "If you are not completely confused by now, you don't begin to understand the problems."

Similar advice can be given to next Chief Executive hopefuls - "If you have no clues about the daunting problems facing the next administration, you don't begin to work out the solutions."

\section{Economic growth}

The first challenge I want to talk about is economic growth.

For many people, Hong Kong's economy peaked in 1997, when the city was basking in what appeared to be a never-ending boom. Yet soon after the Reunification, we were hit by a number of unprecedented crises - the Asian financial crisis in 1998, which led to a rapid shrivelling of demand for our goods and services and a sharp downturn of our economy. World Bank statistics show that our economy contracted 10.98 percent in 1998. From late 2002 to June 2003, the outbreak of the severe acute respiratory syndrome crippled our economy. As a result, we experienced a long bout of deflation. Large numbers of Hong Kong people suffered severely from the nosedive of home values. Anger was boiling over on the eve of the mass protest on 1 July 2003. Our economy did not resume growth until in 2004.

Hong Kong's growth was halted again by the global financial tsunami in 2008. Thanks to the expansionary measures adopted by China, our economy registered a mild decline of -2.46 percent in 2009. Thereafter, but for a rebound of 6.77 percent in 2010, our economy has been registering slow growth. The economic damage caused by the events of 2019 and the outbreak of Covid-19 is well-known.

Hong Kong's economic turmoil since 1997 drives home our vulnerability as a "small and open economy". The point I want to make is that exogenous shocks apart, the real problem with Hong Kong's economy is that we have no economic strategy. Perhaps it is because we have done too well in the past relying on market forces to drive our economy that we have overlooked the need for the government to play a more decisive role in restructuring our economy and stimulating growth, as many other governments have done.

It is interesting to note that despite the many accolades we had received as "the world's freest economy" and our high competitiveness rankings, in the past 40 years, Hong Kong has been led by few Financial Secretaries who had macroeconomic training. Our status as a colony from 1842 to 1997 means that the prime concern of successive Financial Secretaries was to avoid red ink. As a result, bureaucrats who took up the financial mantle had tended to focus on balancing the books, rather than to steer the economy with a strong hand.

A good example of the SAR Government's amateurish attempt to develop a growth strategy is the six "growth industries" announced by then Chief Executive Donald Tsang in early 2009, after Hong Kong was caught off guard by the global financial tsunami. He named six industries - education services, medical services, testing and certification services, environmental industries, innovation and technology, and cultural and creative industries. No data or arguments were put forward as to why those six were chosen. It was only in response to queries from the Legislative Council (LegCo) that Mr. Tsang announced in October 2009 a raft of measures to support those six industries.

I will not go into detail debating the merits of choosing those six "growth" industries. Suffice it to say that, 11 years later, few of the six industries have registered robust growth or contributed meaningfully to restructuring or recharging our economy. Conceptually speaking, it is wrong to regard "innovation and technology" as a stand-alone economic sector. Innovation and technology are drivers of growth and productivity gains that all sectors require. I am glad that the current administration has finally stopped talking about "innovation and technology" as a free-standing economic sector. 
One of the gravest outcomes of the government's inability to intervene in the markets in a timely and effective manner is the "high home price" problem now plaguing Hong Kong. From 2003 to 2020, home prices have shot up 630 percent, from an average of "HK $\$ 2,309$ per square foot in March 2003" to an average of "HK\$14,577 per square foot in March 2020", and going up (Midland Realty, 2017; Ricacorp Properties, 2020). Hong Kong's acute housing problems, as manifested by large numbers of residents who live in abject housing units (we have over 90,000 families living in sub-divided cubicles), the ever-lengthening waiting times for public housing applicants, and the inability of large numbers of decent Hong Kong people to own affordable homes - is believed to be the root cause of the anger of many in our society.

\section{The perils of Hong Kong's narrow economy}

In 2019, Hong Kong's GDP reached US\$366 billion and its per capita GDP US\$48,713. Having lost the bulk of its manufacturing industries to mainland China since China opened up in 1979, the four key industries in Hong Kong in 2019 were financial services (21 percent of GDP and 7.1 percent of workforce); tourism (3.6 percent of GDP and 6 percent of workforce); trading and logistics (19.8 percent of GDP and 17.5 percent of workforce); and professional and other producer services (11.9 percent of GDP and 14.8 percent of workforce) (Census and Statistics Department, 2021). Without manufacturing, Hong Kong's economic structure is much narrower than that of other Asian economies such as Taiwan, Singapore, Republic of Korea and Thailand. Higher-paid jobs with better career prospects are concentrated in finance and professional services. The narrow economic structure led to a narrowing of job opportunities for young people and reduction of their scope for upward mobility. Statistic shows that salaries for fresh graduates have stagnated - the average was HK $\$ 14,250$ in 1997, compared to HK $\$ 14,000$ $\$ 16,000$ in 2020 (University Grants Committee, 2003; Hong Kong Baptist University, 2020). Given the 6.3 times increase of home prices since 2003, there are good reasons for young people to be pessimistic about their future and the prospect of ever owning a decent home.

\section{The HKSAR's belated catch-up effort to embrace technology}

The economy having flourished without much support from the government, other than providing the necessary infrastructure, a low and simple taxation system and a level playing field, Hong Kong's officials never had a good handle on how to encourage local industries to create more value through innovation and greater use of technology.

Hong Kong officials were so lacking in knowledge of technology and recognition of its importance in upgrading the economy that the government did not create a bureau to take charge of promoting innovation and the use of technology until 2015.

The promotion of innovation of technology has a checkered history in Hong Kong. Mr. Tung Chee-hwa started with a bureau responsible for information technology and broadcasting. In 2002, he merged that bureau with one responsible for trade and industry to form a bureau for commerce, industry and technology. When Mr. Donald Tsang was re-elected as Chief Executive in 2007, he had so little interest in technology that he erased technology from government altogether by retitling the "Bureau for Commerce, Industry and Technology" as "Bureau for Commerce and Economic Development". The re-titling fully manifested how little importance the SAR Government attached to innovation and technology, in sharp contrast with the high importance mainland China attached to technological development.

In recent years, in tandem with our nation's massive strive to move up the technology ladder, our government has poured billions into funding for basic R\&D, applied R\&D, state key labs, incubation of technology-based enterprises in the Science Park and Cyberport, matching funds for venture capital investments, smart city, and the Hong Kong-Shenzhen Innovation and Technology Park at Lok Ma Chau. Ample funds were also provided to schools 
PAP

24,2

to stimulate interest in STEM. By 2021-22, over HK $\$ 100$ billion have been allocated to stimulating innovation and technology, but tech contributions to the economy remain insignificant (Financial Services and the Treasury Bureau, 2021).

\section{What are the prescriptions?}

The above account shows that there are major problems with our economy - slow growth, narrow structure, declining competitiveness, widening wealth gap and limited room for upward mobility - which need to be addressed.

Time does not permit me to go into detail about the specific measures that would need to be taken to redress these woes. But clearly the "must do" list of the next administration must include first and foremost, rapid and substantial increase of land and housing supply to provide adequate housing for those without means and affordable housing for all others who want to own decent homes. This would require the government abandoning its "high land price" policy. Even though successive administrations have denied that they have a "high land price" policy, it is undeniable that they have relied heavily on land revenue to pay for mounting government expenditure, and costly public infrastructure projects. The next administration must abandon this heavy reliance on land revenue.

To address the problem of inequality, as manifested by the ever-widening wealth gap, the government would need to adopt more re-distributive measures, by fiscal or other means, to ensure that the fruits of prosperity are shared more evenly.

Finally, to redress the narrowness of our economic structure and hence the limited job opportunities, the government must work closely with its Greater Bay Area partners (the nine leading cities in the Pearl River Delta and Macau) to make full use of the vast resources and market afforded by this economic bloc of 72 million people with a GDP of US $\$ 1,679.50$ billion in 2020 (Constitutional and Mainland Affairs Bureau, 2021).

\section{Conflict management}

The highly violent and destructive protests which took place in 2019 brought to the fore the underlying tensions, latent violence and insecurity in our society, and the role foreign powers played in turning the protests into an insurrection.

The 2019 protests were radically different from other riots and mass protests that Hong Kong had seen. The Hong Kong Government attributed the 1966 disturbances to social discontent, and set up a City District Officer Scheme to improve communications between the government and the people. The 1967 riots were diagnosed as the overspill of the Cultural Revolution in China. The violence gradually subsided in the absence of support from the mainland. The 2003 mass protests quickly returned to peace after Chief Executive Tung Chee-hwa desisted from pressing ahead with enactment of the national security bill which I championed. The 2019 protests were different.

They started as a protest against a bill that would send fugitives to mainland China, Macau and Taiwan. But with abundant support from external elements, well documented in Nury Vittachi's A Secret War in Hong Kong (2020), the protests became an insurgency. The local administration could have been overthrown but for the enactment of the national security law by the National People's Congress Standing Committee on 30 June 2020.

The insurgency had arisen because of Hong Kong's reunification with China. Before 1997, foreign forces used to regard Hong Kong "in a semi-proprietorial way", in the words of Professor Richard Cullen (2021). For this reason, they refrained from causing trouble in their favourite base for watching and spying on China. The change of flag over Hong Kong, and the rising tide of US-led efforts to contain China, heightened immensely Hong Kong's security risks. 
Doubters of foreign involvement in the 2019 insurgency pointed to the participation of large numbers of Hong Kong residents in the initial "peaceful, rational and non-violent" protests as evidence that the rebellion was home-grown. Western media attributed the protests to Hong Kong people's rejection of China's sovereignty over Hong Kong, and declared the "death" of "One Country, Two Systems" in Hong Kong. The western narrative is no doubt biased, but it highlights the tremendous difficulties authorities in Hong Kong have experienced in implementing "One Country, Two Systems" since 1997.

Challenges facing the next Chief Executive

\section{Challenges inherent in the implementation of "One Country, Two Systems"}

Accommodating a small but vibrant and ideologically torn society within a civilizational state like China is never an easy task.

Controversies soon arose after the Reunification.

In January 1999, a major controversy arose pertaining to the interpretation of the Basic Law in the case of NG Ka Ling and Another V. the Director of Immigration (1999), a case concerning the right of abode of children of Hong Kong permanent residents born outside Hong Kong. The Court of Final Appeal's judgment against the government raised vexing questions - Can Hong Kong's judges override "executive-led" government? Does the jurisdiction of the courts of the HKSAR include the power to examine whether the legislative acts of the National People's Congress Standing Committee are consistent with the Basic law and, if found inconsistent, the power to declare them invalid? The Court of Final Appeal's rulings led to the first interpretation of provisions of the Basic Law by the National People's Congress Standing Committee, which was much deplored by the local legal profession.

Then you have the mass protest against the national security bill in 2003; followed by a long litany of sundry protests by the "pan democrats" in Legislative Council, and their supporters, against many issues pertaining to the nation, such as the protest against national education, the building of the high-speed rail and the "co-location" of facilities in West Kowloon, and the national anthem law, culminating in the mass protests against the fugitive offender bill in 2019.

\section{The Central Government's position on Hong Kong's recalcitrance}

The Central Government watched with growing concern the recalcitrance on the part of certain section of our community.

On 26 November 2012, after the conclusion of the 18th plenary of the Communist Party of China, Mr. Zhang Xiaoming, then deputy director in the Hong Kong and Macao Office, wrote an article entitled “Enhancing the Implementation of 'One Country, Two Systems”" (豐富『一國兩 制』實踐) (State Council of the People's Republic of China, 2014). He pointed out that, to maintain a harmonious relationship between the mainland and the SARs, the SAR Government would need to manage "three sets of relationships", or three inherent tensions in the implementation of "One Country, Two Systems" - namely, (1) Vigorously supporting the "One Country" principle while respecting the differences of the SARs' separate systems; (2) upholding the authority of the Central Government and safeguarding the SARs' high degree of autonomy; and (3) leveraging the vast support provided by the motherland while raising the competitiveness of the two SARs.

In early 2013, after Benny Tai Yiu-ting published an article calling for "Occupy Central with LoveandPeace" in the HongKong Economic Journal, senior officials from the Central Government summoned pro-establishment leaders to a meeting in Shenzhen, at which the requirement for the Chief Executive of Hong Kong to be a patriot, among other qualifications, were spelt out.

In June 2014, in the wake of mounting pressure from the "pan democrats" for election of the Chief Executive by universal suffrage, the State Council published the first-ever white paper on The Implementation of “One Country, Two Systems” in Hong Kong (“一國兩制” 在香港 
特別行政區的實踐). The White Paper stressed that the Central Government have "complete jurisdiction” (全面管治權) on Hong Kong, and urged “comprehensive and accurate understanding and implementation of the Basic Law (全面準確理解和貫徹 “一國兩制” 方針政策) (State Council of the People's Republic of China, 2014).

All these steps taken by the Central Government reflect growing concerns about worrisome developments which could wrench Hong Kong from the proper tracks for implementing "One Country, Two Systems" in Hong Kong.

In late 2014, to pressurize the Central Government into accepting election of the Chief Executive by universal suffrage regardless of the provisions of the Basic Law, "Occupy Central" erupted, and paralyzed large swathes of our business districts for 79 days.

In June 2015, the constitutional reform package for the election of the Chief Executive offered by the Central Government on 31 August 2014 was vetoed by the Legislative Council.

On 7 November 2016, the National People's Congress Standing Committee made an interpretation of Article 104 of the Basic Law concerning the taking of oaths of allegiance, following an oath-taking scandal in the Legislative Council during which six legislators insulted the country and the Chinese people in the course of taking their oaths.

In 2017, after Mrs. Carrie Lam took over as Chief Executive, a semblance of harmony between the government and the "pan democrats" was maintained for a year or so. That semblance was brutally shattered after Mrs. Lam initiated legislation to permit the rendition of fugitive offenders to mainland China, Macau and Taiwan in early 2019. The "pan democrats" resorted to physical violence to prevent bills committee meetings from being held, and starting from 9 June, organized mass protests against the resumption of second reading. The rest is history.

On 30 June 2020, "The Law of the People's Republic of China on Safeguarding National Security in the Hong Kong Special Administrative Region” enacted by the National People's Congress Standing Committee entered into force in Hong Kong (Hong Kong Special Administrative Region, 2020).

On 11 November 2020, the National People's Congress Standing Committee made another Decision concerning the qualifications of Members of Hong Kong's Legislative Council, and disqualified four legislators whose qualification as candidates for the LegCo elections originally scheduled to be held on 6 September was ruled invalid by the HKSAR Government.

On 22 February 2021, Mr. Xia Baolong, Director of the Hong Kong and Macau Office, citing authoritative comments made by Mr. Deng Xiaoping in the last century, put forward “patriots govern Hong Kong” (愛國者治港) as the guiding principle for improving Hong Kong's electoral system.

On 11 March 2021, the National People's Congress Standing Committee amended Annex I and Annex II of the Basic law concerning the methods for forming the Chief Executive election committee and the legislature.

On 27 May 2021, the Legislative Council passed the "Improving Electoral System (Consolidated Amendments) Ordinance” 2021. It entered into force on 31 May 2021.

The actions taken by the Central Authorities since June 2020 to fill gaps in our national security laws, lay down strict requirements for the qualifications of Members of the Legislative Council, and reform our electoral rules collectively mark a decisive turning point in Hong Kong's history as a special administrative region.

These measures restored law and order in Hong Kong, and kept the threats to national security by external forces at bay. The electoral reform ensured political security, in the sense that it ensured that important positions of power would not fall into the hands of those opposed to China and function as the proxies of foreign powers.

They also mark a reset of the Central Government's policy toward the implementation of "One Country, Two Systems" in Hong Kong. From a largely hands-off approach immediately after the Reunification, to the gentle exhortation in 2012, the open declaration of "overall responsibility” (全面管治權) in 2014, and the direct actions taken in the past year to ensure 
that Hong Kong would not go off the rails, clearly signify Beijing's determination to ensure "One Country, Two Systems" is implemented according to the original intent of fostering the unity and rejuvenation of the nation.

From the time Mr. Deng Xiaoping put forward the "One Country, Two Systems" formula, it has been a reunification project. It is a project to promote national unity and foster the rejuvenation of the nation. The message is clearly that espousing our nation is the foundation of our separate systems, and a pre-condition for the continued success of this unique arrangement.

But it should be noted that Mr. Xia Baolong also said that "patriots govern Hong Kong" does not mean that Hong Kong must have only “one (political) colour” (清一色). Hong Kong is a region well known for the confluence of Chinese and western cultures, and the diversity of its society. There will always be room for those raised in Hong Kong's capitalist ideology to contribute to the governance of Hong Kong.

After this major reset, as the chief implementer of "One Country, Two Systems", it will be the responsibility of the next Chief Executive to strengthen Hong Kong's characteristics as an open, diverse and vibrant international city, so that Hong Kong can continue to stand apart from the rest of the nation and contribute to the welfare of the nation in its unique way.

\section{Managing change and continuity}

Recently, a political party urged that there be "no change for another 50 years". This mantra was put forward to assuage worries about Hong Kong's separate systems coming to an end in 2047, but it is unrealistic to insist that there be no change.

The reality is Hong Kong's constitutional status has changed on China's resumption of the exercise of sovereignty on 1 July 1997. Hong Kong has become an integral part of China, and the integration process is bound to gather pace in the coming years.

Hong Kong's competitive environment has changed dramatically. The meteoric rise of China as the world's largest trading nation and second largest economy has changed radically Hong Kong's competitive position in the nation and in the world economy. The rise of China's economy has called into question the validity of Hong Kong continued adherence to its old economic model - it is much vaunted "small government, big market", and supposedly "non-interventionist" philosophy.

Hong Kong's political system has also undergone a sea change following the introduction of mass elections in the 1990s. The increase in mass participation in governance has upended the old, "elite consensual" model. The "pan democrats" turned the legislature into a "vetocracy", and wrought great damage to the efficacy of the governance of the executive branch. In the past 24 years, successive administrations have gone through major crises brought by conflicts with the pan dem-dominated legislature, and a near-breakdown in 2019. The next administration needs to bring about a re-equilibrium.

The civil service has been content to remain in the pre-1997 mould of being a pure-play technocracy, in disregard of the constitutional change and the political mission of upholding original intent and purpose of "One Country, Two Systems". Far too many still regard the public service merely as well-paid jobs rather than a career and a mission to serve the country. Far too many are accustomed to working at their old pace, paying heed only to technical rules, regulations and precedents and not moving fast enough to resolve the pressing problems of the moment.

The world is changing fast and we cannot afford to stand still. Much reform is needed, which is why " 50 years no change" is not an option. Hong Kong needs to change to keep abreast the times, while maintaining continuity of its unique, separate systems. By that I mean its rule of law, its commitment to clean government, its cultural diversity, staunch protection of rights and freedoms, and its ability to communicate and work with the international community. I believe these are Hong Kong's unique fortes, and it behoves the next Chief Executive to maintain Hong Kong's unique advantages within the framework of "One Country". 
PAP

24,2

124

\section{References}

Census and Statistics Department (2021), Hong Kong Monthly Digest of Statistics: January 2021, Hong Kong Special Administrative Region, Hong Kong.

Constitutional and Mainland Affairs Bureau (2021), "Greater Bay Area Overview", available at: https://www.bayarea.gov.hk/en/about/overview.html (accessed 25 June 2021).

Cullen, R. (2021), "Hong Kong judge concerned with US intervention in Hong Kong affairs", available at: https://johnmenadue.com/hong-kong-judge-concerned-with-us-intervention-in-hong-kongaffairs/ (accessed 25 June 2021).

Financial Services and the Treasury Bureau (2021), “The 2021-22 Budget”, available at: https://www. budget.gov.hk/2021/eng/budget28.html (accessed 25 June 2021).

Hong Kong Baptist University (2020), "Greater Bay Area Pay and Benefits Survey 2020 Released", available at: https://research.hkbu.edu.hk/news/greater-bay-area-pay-and-benefits-survey-2020released (accessed 25 June 2021).

Hong Kong Special Administrative Region (2020), "The Law of the People's Republic of China on Safeguarding National Security in the Hong Kong Special Administrative Region”, available at: https:/www.gld.gov.hk/egazette/pdf/20202448e/egn2020244872.pdf (accessed 25 June 2021).

Midland Realty (2017), “回歸20年 樓價「十上十落」”, available at: https://bit.ly/3hubP0v (accessed 25 June 2021).

Ng Ka Ling and Another V. The Director of Immigration (1999), 1 HKLRD 315, Court of Appeal, Hong Kong.

Ricacorp Properties (2020), “50指標屋苑平均呎價錄13月最大升幅 五月報14,951元升1.7\%後市仍 看浱”, available at: https://bit.ly/3k17hQM (accessed 25 June 2021).

State Council of the People's Republic of China (2014), White paper on the Practice of the "One Country, Two Systems” Policy in the Hong Kong Special Administrative Region, The Information Office of the State Council, PRC.

University Grants Committee (2003), "Average annual salaries of graduates of full-time UGC-funded programmes who were in full-time employment by level of study and broad academic programme category, $1996 / 97$ to 2002/03", available at: https://cdcf.ugc.edu.hk/cdcf/ searchStatSiteReport.action\# (accessed 25 June 2021).

Vittachi, N. (2020), The Other Side of the Story: A Secret War in Hong Kong, YLF Hong Kong, Hong Kong.

\section{About the author}

The Hon. Mrs. Regina Suk-yee Ip Lau, GBM, GBS, JP is a First Class Honor graduate in English of the University of Hong Kong in 1972, earned three master degrees at different stages: Master of Letters in Renaissance Poetry at the University of Glasgow, Sloan Management Program at Stanford University, and Master of Art in East Asian Studies at Stanford University. She joined the Hong Kong Government in 1975, rising to the position of Secretary for Security and resigned in 2003. On her return from further studies in the US, she established a think tank, Savantas Policy Institute in 2006. She was elected as Member of the Legislative Council in 2008, 2012 and 2016, founded the New People's Party (NPP) in 2011, and was appointed as Non-Official Member of the Executive Council in 2012. She established the "Maritime Silk Road Society" (MSRS) in 2015. In December 2016, Mrs. Ip resigned from the Executive Council, and ran in both 2012 and 2017 Chief Executive elections. Regina Suk-yee Ip Lau can be contacted at:iplau@reginaip.hk

For instructions on how to order reprints of this article, please visit our website:

www.emeraldgrouppublishing.com/licensing/reprints.htm

Or contact us for further details: permissions@emeraldinsight.com 